\title{
Markers of Carotid Atherosclerosis in Patients with Type 2 Diabetes Mellitus
}

\section{Daniel Petrovič ${ }^{*}$}

Institute of Histology and Embryology, University of Ljubljana, Korytkova 2, 1105 Ljubljana, Slovenia

*Corresponding author: Daniel Petrovič, Faculty of Medicine, MD, PhD, FESC, Institute of Histology and Embryology, University of Ljubljana, Korytkova 2, 1105 Ljubljana, Slovenia, Tel: +38615437467; Fax: +38615437361; E-mail: daniel.petrovic@mf.uni-lj.si

Received date: Sep 26, 2016; Accepted date: Sep 28, 2016; Published date: Sep 30, 2016

Copyright: ( 2016 Petrovic D. This is an open-access article distributed under the terms of the Creative Commons Attribution License, which permits unrestricted use, distribution, and reproduction in any medium, provided the original author and source are credited.

\section{Editorial}

It is generally accepted that beside cholesterol accumulation, chronic inflammation and immune system are very much involved in the pathogenesis of atherosclerosis [1]. A genetic variability of the candidate genes implicated in atherosclerosis (i.e. candidate genes of inflammation, oxidative stress, growth factors, renin-angiotensin aldosterone system, and so-forth) has so far been demonstrated in several reports to affect the development of atherosclerosis [2]. Genetic variability in the candidate genes implicated in atherosclerosis may alter their transcriptional activity and contribute to susceptibility to cardiovascular disease [3-11]. In the pathogenesis of atherosclerosis genetic, environmental, and epigenetic factors are involved [4-5].

Genetic and epigenetic factors may be studied with two main approaches, candidate gene approach and genome wide association study (GWAS) approach [4-9,11]. Candidate gene approach is hypothesis-driven approach, whereas in GWAS approach appropriate subset of patients (i.e. patients with coronary artery disease, myocardial infarction, T2DM, bronchial asthma, Crohn disease and so forth) are genetically analyzed and distribution of genotypes/alleles compared with appropriate control subjects [4-8].

In cardiovascular research, $\mathrm{s}$ great potential of systems-based methodologies has been demonstrated in several phenotypes, including atherosclerosis [4,5]. Omics data (genomics, proteomics, metabolomics, transcriptomics, epigenomics, nutriepigenomics) are becoming widely available by progress in high-throughput molecular profiling. However, integration between the omics data, biological sciences, clinical data and other clinical diagnostic modalities are going to be essential for the success of translation of integrative analysis of biological biomarkers into the clinical practice.

There are two non-invasive markers of carotid atherosclerosis available, carotid intima-media thickness (CIMT) and carotid atherosclerosis (demonstrated as number of affected segments of carotid arteries, the sum of plaques thickness). In last decade it has been accepted that CIMT is biologically distinct from atherosclerotic plaques, not really atherosclerosis, but both represent an indicator for cardiovascular risk [12]. In contrast, carotid plaques are a characteristic phenotype of atherosclerosis, not a simple continuum of CIMT progression, and predict the cardiovascular disease better than CIMT $[12,13]$

So far, several studies using either candidate gene approach or GWAS approach have been reported several genetic markers for either CIMT or subclinical carotid atherosclerosis, however most reports studied patients in general population, and only few enrolled subjects with type 2 diabetes mellitus (T2DM) [4-9,11]. It should be emphasized, however, that whatever approach (candidate gene or GWAS approach) may be used, crucial is well-designed and appropriately selected study group. Moreover, according to expected great increase in the incidence of T2DM in coming years, patients with T2DM should be studied more often.

In patients with $\mathrm{T} 2 \mathrm{DM}$, cardiovascular complications are reported about 15 years earlier than in the population without T2DM, and they have worse prognosis as well $[14,15]$. Beside traditional risk factors identified in the general population, such as arterial hypertension, dyslipidemia, cigarette smoking and parental history of cardiovascular diseases, T2DM and different genetical factors also contribute to the high prevalence of cardiovascular disease in patients with diabetes mellitus [14-16].

To conclude, good cooperation between clinicians, geneticists, biologists, epidemiologists, statisticians, and computing scientists are essential for advance of carotid artery disease and cardiovascular diseases in general [14-16]. Secondly, well-designed and appropriately powered studies are needed to enroll different subset of patients with different environmental and genetical background.

\section{References}

1. Libby P, Hansson GK (2015) Inflammation and immunity in diseases of the arterial tree: players and layers. Circ Res 116: 307-311.

2. Jerrard-Dunne P, Sitzer M, Risley P, Buehler A, von Kegler S, et al. (2004) Inflammatory gene load is associated with enhanced inflammation and early carotid atherosclerosis in smokers. Stroke 35: 2438-2443.

3. Humphries SE, Luong LA, Talmud PJ, Frick MH, Kesäniemi YA, et al (1998) The 5A/6A polymorphism in the promoter of the stromelysin-1 (MMP-?3) gene predicts progression of angiographically determined coronary artery disease in men in the LOCAT gemfibrozil study. Atherosclerosis 139: 49-56

4. Elashoff MR, Wingrove JA, Beineke P, Daniels SE, Tingley WG, et al. (2011) Development of a blood-based gene expression algorithm for assessment of obstructive coronary artery disease in non- diabetic patients. BMC Med Genomics 4: 26

5. Vidal M, Cusick ME, Barabási AL (2011) Interactome networks and human disease. Cell 144: 986-998.

6. Geisel MH, Coassin S, Heßler N, Bauer M, Eisele L, et al. (2016) Update of the effect estimates for common variants associated with carotid intima media thickness within four independent samples: The Bonn IMT Family Study, the Heinz Nixdorf Recall Study, the SAPHIR Study and the Bruneck Study. Atherosclerosis 249: 83-87.

7. Adams HH, Ikram MA, Vernooij MW, van Dijk AC, Hofman A, et al. (2016) Heritability and Genome-Wide Association Analyses of Intracranial Carotid Artery Calcification: The Rotterdam Study. Stroke 47: 912-917.

8. Vargas JD, Manichaikul A, Wang XQ, Rich SS, Rotter JI, et al. (2016) Common genetic variants and subclinical atherosclerosis: The Multi-Ethnic Study of Atherosclerosis (MESA). Atherosclerosis 245: 230-236.

9. NINDS Stroke Genetics Network (SiGN), International Stroke Genetics Consortium (ISGC) (2015) Loci associated with ischaemic stroke and its subtypes (SiGN): a genome-wide association study. Lancet Neurol 15: 174-184. 
Citation: Petrovic D (2016) Markers of Carotid Atherosclerosis in Patients with Type 2 Diabetes Mellitus. J Diabetic Complications Med 1: e102.

Page 2 of 2

10. Reilly MP, Li M, He J, Ferguson JF, Stylianou IM, et al. (2011) Identification of ADAMTS7 as a novel locus for coronary atherosclerosis and association of $\mathrm{ABO}$ with myocardial infarction in the presence of coronary atherosclerosis: two genome-wide association studies. Lancet 29: 383-392.

11. Popovic D, Starcevic JN, Letonja MS, Makuc J, Vujkovac AC, et al. (2016) Polymorphism rs5498 of the ICAM-1 gene affects the progression of carotid atherosclerosis in patients with type 2 diabetes mellitus. Lipids Health Dis 15: 79.

12. Lorenz MW, Markus HS, Bots ML, Rosvall M, Sitzer M (2007) Prediction of clinical cardiovascular events with carotid intima-media thickness: a systematic review and meta-analysis. Circulation 115: 459-467.

13. Rundek T, Brook RD, Spence JD (2007) Prediction of clinical cardiovascular events with carotid intima-media thickness: a systematic review and meta-analysis. Circulation 116: e317.
14. Grundy SM, Benjamin IJ, Burke GL, Chait A, Eckel RH, et al. (1999) Diabetes and cardiovascular disease: a statement for healthcare professionals from the American Heart Association. Circulation 100: 1134-1146.

15. Booth GL, Kapral MK, Fung K, Tu JV (2006) Relation between age and cardiovascular disease in men and women with diabetes compared with non-diabetic people: a population-based retrospective cohort study. Lancet 368: 29-36.

16. Manolio TA, Collins FS, Cox NJ, Goldstein DB, Hindorff LA, et al. (2009) Finding the missing heritability of complex diseases. Nature 461: 747-753. 